\title{
Evaluation of heavy metal content in water and removal of metals using native isolated bacterial strains
}

\author{
LAILA IBRAHIM FAQE SALIH ${ }^{1, \boldsymbol{v}}$, REZAN OMER RASHED ${ }^{2}$, SIRWAN MUHSIN MUHAMMED ${ }^{2}$ \\ ${ }^{1}$ Department of General Science, College of Education and Languages, University of Charmo. Peshawa Street, Chamchamal/Sulaimani City, Kurdistan \\ Region, F.R. Iraq, Tel.: +96-4538973352, ^email: laila.ibrahim@ charmouniversity.org \\ ${ }^{2}$ Department of Biology, School of Science, University of Sulaimani. Kirkuk Road, Sulaimani, Kurdistan Region, F. R. Iraq
}

Manuscript received: 29 Mei 2021. Revision accepted: 11 July 2021.

\begin{abstract}
Saleh LIF, Rashed RO, Muhammed SM. 2021. Evaluation of heavy metal content in water and removal of metals using native isolated bacterial strains. Biodiversitas 22: 3163-3174. Natural surface water sources are susceptible to chemical contamination, including heavy metals. The goals of this study were to isolate naturally occurring heavy metal-tolerant bacteria by evaluating their ability to remove heavy metals from Tanjaro River and assessing the river's water quality. The potency of bacteria to remove heavy metals $(\mathrm{Cd}, \mathrm{Pb}, \mathrm{Cu}, \mathrm{Cr}, \mathrm{Ni}, \mathrm{Zn}, \mathrm{Co}$, and $\mathrm{Fe})$ from the medium was conducted by inductively coupled plasma-optical emission spectrometry. Results of physicochemical parameters of the water samples were as follows: temperature $11.9-31^{\circ} \mathrm{C}, \mathrm{pH} 6.1-8.64$, total dissolved solids $268-464 \mathrm{mg} . \mathrm{l}^{-1}$, total hardness $232-485 \mathrm{mg} . \mathrm{l}^{-1}$, and alkalinity $122-324.3 \mathrm{mg} . \mathrm{l}^{-1}$. The overall mean concentrations of the heavy metals were in the order of $\mathrm{Zn}>\mathrm{Cu}>\mathrm{Pb}>\mathrm{Ni}>\mathrm{Co}>\mathrm{Fe}>\mathrm{Cr}>\mathrm{Cd}$ ), with values of 0.086, 0.073, 0.71, 0.068, 0.051, 0.056, 0.031, and $0.024 \mathrm{ppm}$, respectively Moreover, the concentrations were generally exceeded the water quality criteria of WHO in some observations. The isolates included both gram-negative (56.5\%) and gram-positive (43.5\%) bacteria. The isolates displayed different degrees of resistance to heavy metals with maximum tolerable concentrations (MTCs) ranging from (10-250) ppm. Bacillus safensis and Leucobacter chromiiresistens were respectively able to tolerate $(80,90 \mathrm{ppm}) \mathrm{Cd},(250,160 \mathrm{ppm}) \mathrm{Pb},(210,100 \mathrm{ppm}) \mathrm{Cr},(110,90 \mathrm{ppm})$ $\mathrm{Ni}$ and $(160,170 \mathrm{ppm}) \mathrm{Co}$, while, Proteus mirabilis could tolerate $90 \mathrm{ppm} \mathrm{Cd}$. The isolates were able to remove $55.4 \% \mathrm{~Pb}, 53.1 \% \mathrm{Cr}$, $53.7 \% \mathrm{Ni}, 47.7 \mathrm{Fe}, 61.4 \% \mathrm{Co}$, and $55.8 \% \mathrm{Cu}$ from a medium supplemented with the mixture of these heavy metals. The finding of this study indicated that Tanjaro River was undergoing frequent changes in water quality. Native bacterial isolates possessed considerable tolerance to selected heavy metals, which provides promising candidates for use in bioremediation.
\end{abstract}

Keywords: Bacteria, bioremediation, heavy metals, physicochemical parameter, tolerance, water quality

Abbreviations: Cd: cadmium; Co: cobalt; $\mathrm{Cr}$ : chromium; $\mathrm{Cu}$ : copper; $\mathrm{Fe}$ : iron; $\mathrm{HCl}$ : hydrochloric acid; $\mathrm{HNO}_{3}$ : nitric acid; ICP-OES: Inductively coupled plasma-optical emission spectrometry; L.B: Luria-Bertani; Ni: nickel; Pb: lead; SPSS: Statistical Package for the Social SciencesZn: zinc

\section{INTRODUCTION}

Chemical pollution monitoring of surface water helps to determine the level of environmental risk associated with pollutants that are toxic to aquatic organisms and enables the evaluation of their accumulation in the ecosystem (Michalec et al. 2014), since there are no sufficient treatment facilities for the treatment of municipal and industrial waste, effluents are directly discharged into water bodies, causing surface water contamination and reducing water quality (Bui et al. 2016). According to recent studies, the long-term usage of untreated wastewater from industrial sources can degrade water quality and rendering it unsafe for human consumption (Kapahi and Sachdeva 2019). Dumping a significant amount of industrial and household pollutants into rivers make considerable stress on the river's physicochemical and microbiological content (Haque et al. 2019). Industrial effluent containing heavy metals poses a health risk to plants, animals, humans, and aquatic life (Marzan et al. 2017), they not only produce toxic or chronic poisoning in aquatic lives but also pose threat to the environment (Ma et al. 2020). Heavy metals are naturally occurring elements that have a relatively high atomic weight and density (greater than $5 \mathrm{~g} . \mathrm{cm}^{-3}$ ) compared to water (Afzal et al. 2017). The term heavy metal is collectively used for certain categories of metals, metalloids, lanthanides, and actinides. These compounds can enter natural waters from various sources. Some heavy metals are present at low concentrations but are biologically significant in the aquatic environment, while others pose a critical risk to human health and the environment due to their widespread occurrence as contaminants, accumulation in biota, their carcinogenic, mutagenic, and non-biodegradable nature, and their ability to persist in the environment (Rahman and Singh 2016). The toxicity of metal ions are resulting from their competition with or replacement of a functional metal can cause conformational changes, denaturation and deactivation of enzymes, and the destruction of cell and organelle integrity (El-Shanshoury et al. 2013), they have a variety of negative impacts on biological processes, most of which are related to metal species, solubility, and concentration, effluent properties such as $\mathrm{pH}$, the presence and concentration of other ions and suspended particles 
(Bestawy et al. 2013). An increased pollutant load in freshwater increases the nutrient level in the water and can alter the $\mathrm{pH}$ and other physicochemical properties of water bodies (Chaurasia and Tiwari 2001). These surface water alterations act as a selective force on bacterial communities, causing them to develop resistance to heavy metals and antibiotics (Aktan et al. 2012). Recently, heavy metal bioremediation using microorganisms has received increasing attention; they can be used for metal remediation by removing, concentrating, and recovering metals from contaminated sites (Irawati et al. 2017). Microorganisms and microbial products can be effective bioaccumulation of metals in both soluble and particulate forms (Shukla et al. 2017). Several microorganisms have developed detoxification and respiration mechanisms that use heavy metals and are thus resistant to them (Marzan et al. 2017). Long-term metal exposure is hypothesized to impose selection pressure on bacteria, favoring the development of tolerable microorganisms with mechanisms to resist heavy metals through efflux, complexation, and reduction of metal ions (Jamil et al 2018). The ability of microorganisms to detoxify metal contamination can be used for bioremediation; isolation and characterization of bacteria from metal-contaminated environments should be carried out in order to identify metal-resistant strain candidates that could be used for heavy metal removal and bioremediation (Rajbanshi 2008). Therefore, the aim of this study was to isolate, molecularly characterize, and analyze the bioremediation potential of heavy metal-tolerant bacteria isolates, as well as determine heavy metal concentrations in water samples from the Tanjaro River.

\section{MATERIALS AND METHODS}

\section{Study area}

The study was carried out along the Tanjaro River, which is a permanent river situated $7 \mathrm{~km}$ southwest of Sulaimani City (Sulaimaniyah), Sulaimani Governorate, Kurdistan Regions, Iraq. The river is created by linking two major streams Kani-Ban and Qiliasan with other small tributaries crossing many urban and agricultural regions (Mustafa 2006). It is used as a source for irrigation and livestock consumption purposes. Finally, it contributes to the Darbandikhan dam, which serves as a supply of drinkable water for the Darbandikhan district, as well as a source of fish, tourism, and hydropower (Rashid 2010). The sources of Tanjaro river pollution are black water and residual materials from motor oil recycling, hospitals, industry, and agriculture run directly into the Tanjaro River through a combined sewerage system (Othman et al 2017; Aziz et al. 2012). Tanjaro river pollution leads to evanescence of rice cultivation and the extinction of fisheries in the River (Rasheed and HamaKarim 2017). The sample locations have geographical coordinates of $35^{\circ} 16$ ' 35 " N $45^{\circ} 51$ '9 " E, as shown in (Figure 1).
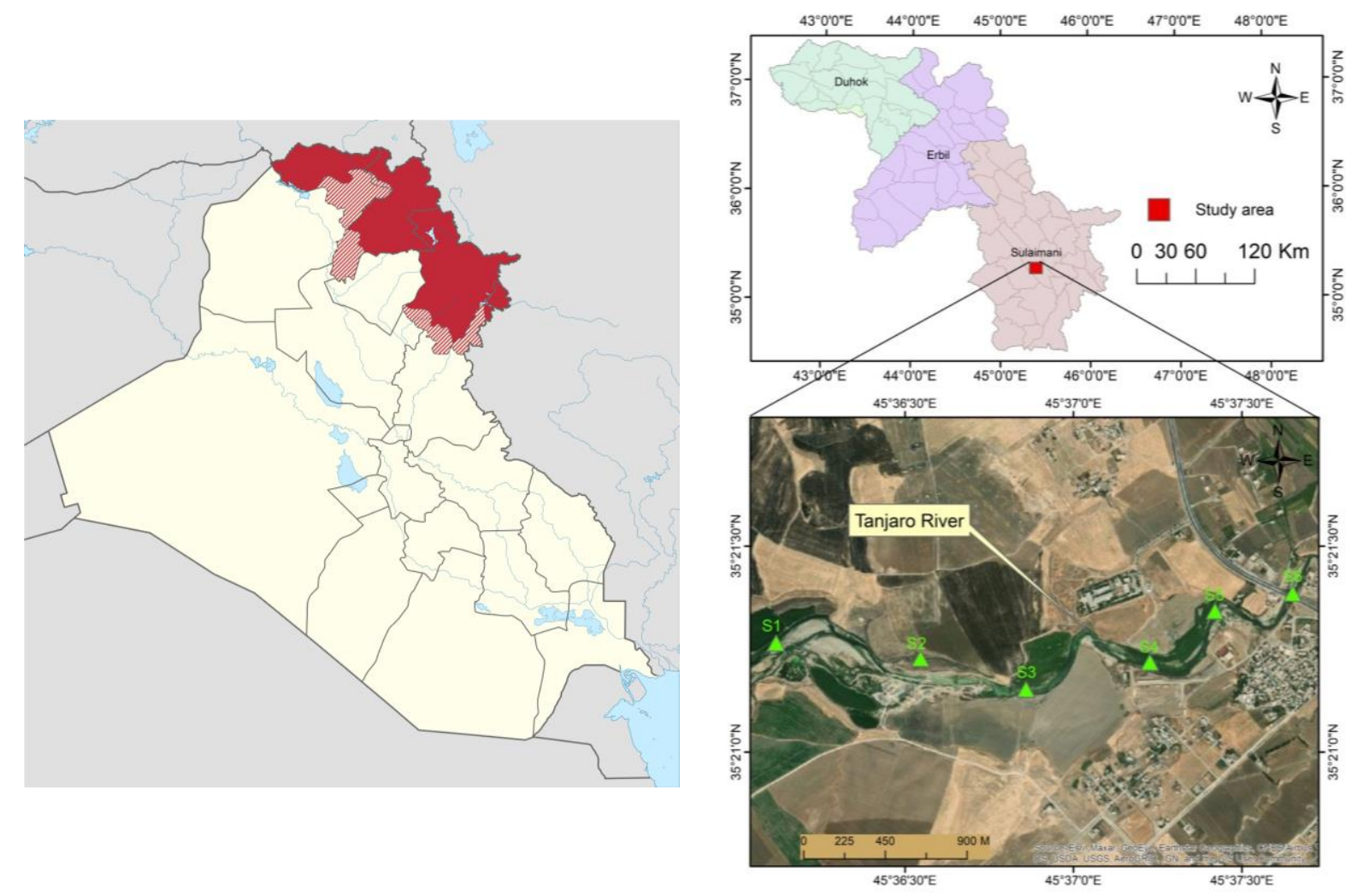

Figure 1. Study area located along the Tanjaro River in Sulaimani Governorate, Kurdistan Regions, F.R. Iraq 
Table 1. List of sampling sites and their geographical specification

\begin{tabular}{lc}
\hline Coordinates & Sites \\
\hline $35.35444 \mathrm{~N} 45.601955 \mathrm{E}$ & $\mathrm{S} 1$ \\
$35.353762 \mathrm{~N} 45.609093 \mathrm{E}$ & $\mathrm{S} 2$ \\
$35.352564 \mathrm{~N} 45.614319 \mathrm{E}$ & $\mathrm{S} 3$ \\
$35.352344 \mathrm{~N} 45.620424 \mathrm{E}$ & $\mathrm{S} 4$ \\
$35.356574 \mathrm{~N} 45.622611 \mathrm{E}$ & $\mathrm{S} 5$ \\
$35.356431 \mathrm{~N} 45.627525 \mathrm{E}$ & $\mathrm{S} 6$ \\
\hline
\end{tabular}

\section{Sample collection and preparation}

A total of 54 water samples were collected over 9 months from January to October 2019. Each month, three replicates of each sample were collected from six sampling sites along the river, designated as S1 to S6 (Table 1). All water samples were analyzed monthly for physicochemical parameters and once per season, the water samples were analyzed for heavy metals and bacterial detection. The sampling, preservation, and transfer of the water samples were conducted according to standard procedures. The acid digestion method was performed for heavy metal detection. The water samples were digested by adding $2 \mathrm{~mL}$ of $1: 1$ $\mathrm{HNO}_{3}$ and $10 \mathrm{~mL}$ of $1: 1 \mathrm{HCl}$ then heated until the volume decreased to $25 \mathrm{~mL}$. The volume was then adjusted to 100 $\mathrm{mL}$ by adding double-distilled water. The analysis was conducted using an Optima $7300 \mathrm{~V}$ inductively coupled plasma-optical emission spectrometer (ICP-OES), as described by (APHA 2011).

\section{Physicochemical analysis}

Water temperature $(\mathrm{T}), \mathrm{pH}$, electrical conductivity (EC), and total dissolved solids (TDS) were analyzed in situ with a portable water quality tester, while total hardness and alkalinity were analyzed according to standard methods (Bartram and Balance 1996).

\section{Preparation of metal solutions}

The metals $(\mathrm{Cd}, \mathrm{Pb}, \mathrm{Cu}, \mathrm{Cr}, \mathrm{Ni}, \mathrm{Zn}, \mathrm{Co}$, and $\mathrm{Fe}$ ) were used as $\mathrm{CdSO}_{4} \cdot 4 \mathrm{H}_{2} \mathrm{O}, \quad \mathrm{Pb}\left(\mathrm{CH}_{3} \mathrm{COO}\right)_{2} \cdot 3 \mathrm{H}_{2} \mathrm{O}, \mathrm{CuSO}_{4}$, $\mathrm{K}_{2} \mathrm{Cr}_{2} \mathrm{O}_{7}, \mathrm{Ni}\left(\mathrm{NO}_{3}\right)_{2} \cdot 4 \mathrm{H}_{2} \mathrm{O}, \mathrm{Zn}\left(\mathrm{CH}_{3} \mathrm{CO}_{2}\right)_{2}, \mathrm{CoCl}_{3} \cdot 6 \mathrm{H}_{2} \mathrm{O}$, and $\mathrm{FeCl}_{3}$, respectively. Stock solutions (1000 ppm) were prepared by dissolving metal salts in distilled water. The metallic salts were of analytical grade, and the stock solutions were filter-sterilized with $0.22 \mu \mathrm{m}$ pore size Millipore membranes and added to $45^{\circ} \mathrm{C}$ sterilized medium (Silva et al. 2012).

\section{Primary screening of heavy metal-resistant bacteria}

Aseptically collected water samples were serially diluted and inoculated on L.B agar medium separately supplemented with $10 \mathrm{ppm}$ of various heavy metal salts $\left(\mathrm{CdSO}_{4} \cdot 4 \mathrm{H}_{2} \mathrm{O}, \mathrm{Pb}\left(\mathrm{CH}_{3} \mathrm{COO}\right)_{2} \cdot 3 \mathrm{H} 2 \mathrm{O}, \mathrm{CuSO}_{4}, \mathrm{~K}_{2} \mathrm{Cr}_{2} \mathrm{O}_{7}\right.$, $\mathrm{Ni}\left(\mathrm{NO}_{3}\right)_{2} \cdot 4 \mathrm{H}_{2} \mathrm{O}, \mathrm{Zn}\left(\mathrm{CH}_{3} \mathrm{CO}_{2}\right)_{2}, \mathrm{CoCl}_{3} \cdot 6 \mathrm{H}_{2} \mathrm{O}$, and $\left.\mathrm{FeCl}_{3}\right)$. The cultures were incubated at $37^{\circ} \mathrm{C}$ for $24-48$ hours. Colonies were selected for further isolation to obtain single colonies. Gram staining was used to examine the morphology of the bacterial cells under a light microscope (Aktan et al. 2012; Ndeddy and Babalola 2017).

\section{Determination of maximum tolerable concentration of heavy metals}

The maximum tolerable concentration to eight selected metal salts was carried out using the 96-well microtiter plate method. Bacterial isolates were precultured for $24 \mathrm{hr}$ in liquid L.B medium at $37^{\circ} \mathrm{C}$ and $120 \mathrm{rpm}$ until reaching an optical density of 0.6 at $600 \mathrm{~nm}$. Next, $50 \mu \mathrm{l}$ of the preculture was added to $150 \mu \mathrm{l}$ of LB broth containing 20 ppm of a heavy metal compound as starter. The mixture was transferred into a 96-well microplate and incubated at $37^{\circ} \mathrm{C}$ for $48 \mathrm{hr}$, at which point the maximum tolerable concentration (MTC) was determined using a microplate reader. The MTC was defined as the highest concentration of heavy metal that allowed growth after 2 days. Strains showing the highest tolerance to each heavy metal were tested for their heavy metal removal efficacy as described by (Cai et al. 2019; Sultan et al. 2020) with some modifications.

\section{Molecular diagnostic assay \\ PCR amplification and I6S rRNA sequencing}

Bacterial genomic DNA of the isolates was extracted using a Presto mini gDNA extraction kit (Geneaid Biotech Ltd) according to the manufacturer's instructions. PCR analysis was performed with a Mega Cycler PCR using universal bacterial 16S rDNA primers from (Satokari et al. 2001): 7F (5'AGAGTTTGATYMTGGCTCAG-3') and 1015R (5'ACGGYTACCTTGTTACGACTT-3') The PCR program was: initial denaturation temperature of $95^{\circ} \mathrm{C}$ for 5 min, followed by 35 cycles of $95^{\circ} \mathrm{C}$ for $30 \mathrm{sec}, 60^{\circ} \mathrm{C}$ for 30 sec, $72^{\circ} \mathrm{C}$ for $3 \mathrm{~min}$, a final extension temperature of $72^{\circ} \mathrm{C}$ for $5 \mathrm{~min}$, and a $4^{\circ} \mathrm{C}$ hold. DNA sequencing was performed by the Sanger method using a 3500xl Genetic Analyzer (Applied Biosystems).

\section{Determining of heavy metal removal efficacy}

The heavy metal removal potential of the tolerant bacteria was assessed in a batch experiment process. A 500 $\mathrm{mL}$ bottle containing $200 \mathrm{~mL}$ of L.B broth was prepared separately for each metal $(\mathrm{Cd}, \mathrm{Pb}, \mathrm{Cu}, \mathrm{Cr}, \mathrm{Ni}, \mathrm{Zn}, \mathrm{Co}$, and $\mathrm{Fe}$ ) and inoculated with $2 \mathrm{~mL}$ of 18 -h old bacterial culture with OD600 of 0.6. The cell culture was incubated at $37^{\circ} \mathrm{C}$ and $120 \mathrm{rpm}$ for $24 \mathrm{hr}$. The culture was then centrifuged (Sigma S-16P) at $5000 \mathrm{rpm}$ for $20 \mathrm{~min}$ at $4^{\circ} \mathrm{C}$. The supernatant was digested with $\mathrm{HNO}_{3}$ at $100^{\circ} \mathrm{C}$. Heavy metal concentrations in the medium before bacteria inoculation and after the $24 \mathrm{~h}$ culturing were detected by ICP-OES (Optima 7300 V). The same treatment without the inoculation of bacterial strains was used as a control for each heavy metal. The results were compared with the control to calculate the heavy metal remediation capacity (\%) as follows:

$\%$ of heavy metal utilized $=$ Heavy metal utilized $/$ Heavy metal added to the L.B broth ppm $\times 100$

Heavy metal utilized = Heavy metal added to the LB broth - Heavy metal remaining at the end of culture (Afzal et al. 2017; Marzan et al. 2017). 


\section{Statistical analysis}

The SPSS program (Statistical Package for the Social Sciences) version 23 was used to statistically analyze the results. The analyzed parameters were processed using the variance method (ANOVA) followed by Duncan's test to determine the existence or absence of significant differences between sample events (Ravanbakhsh et al. 2009).

\section{RESULTS AND DISCUSSION}

\section{Distribution of physicochemical parameters}

The physicochemical parameters (temperature, $\mathrm{pH}, \mathrm{EC}$, TDS, alkalinity, and hardness) of the water samples measured during the study period on monthly basis are shown in (Tables 2 and 3), while the heavy metal concentrations $(\mathrm{Cd}, \mathrm{Pb}, \mathrm{Cu}, \mathrm{Cr}, \mathrm{Ni}, \mathrm{Zn}, \mathrm{Co}$, and $\mathrm{Fe})$ in the water samples are given in (Figure 2).

The lowest water temperature was $11.9^{\circ} \mathrm{C}$ and was recorded in January 2019 at S1, while the highest was $31^{\circ} \mathrm{C}$ in August at $\mathrm{S} 1$ and S6; the yearly mean temperature was $11.2^{\circ} \mathrm{C}$. The $\mathrm{pH}$ values of the river water ranged from 6.3 to 8.64; the minimum value was recorded at S6 in October, while the maximum was recorded at S2 in August. The results indicated that there were only significant differences among studied sits at $(\mathrm{P}<0.05)$. The conductivity of water is affected by suspended matter and also depends upon the amount of ions in the water. The lowest conductivity was $525 \mu \mathrm{S} . \mathrm{cm}^{-1}$ at $25^{\circ} \mathrm{C}$ and was observed in February. From February onwards, the conductivity increased and reach its highest value of $928 \mu \mathrm{S} . \mathrm{cm}^{-1}$ at $25^{\circ} \mathrm{C}$ in September. Conductivity is strongly related to the amount of TDS, which was confirmed by observing a maximum TDS of $464 \mathrm{mg} / \mathrm{l}$ in September. The lowest total hardness value was $232 \mathrm{mg} . \mathrm{l}^{-1}$, recorded in April, while the highest was $485 \mathrm{mg} . \mathrm{l}^{-1}$ recorded in June at S2. During January and February, the water alkalinity was lower than the permissible level $\left(200 \mathrm{mg} \cdot \mathrm{l}^{-1}\right)$. After February, the alkalinity increased to exceed the permissible level. The chloride concentration during the study period ranged from 13.2$77.9 \mathrm{mg} . \mathrm{l}^{-1}$.

\section{Metal content of the water samples}

The ICP-OES results of heavy metal are shown in (Figure 2). Among the analyzed heavy metals, $\mathrm{Zn}$ ions had the highest concentration, while $\mathrm{Cd}$ and $\mathrm{Cr}$ ions had the lowest concentrations as in the follows order: $\mathrm{Zn}>\mathrm{Cu}>$ $\mathrm{Pb}>\mathrm{Ni}>\mathrm{Co}>\mathrm{Fe}>\mathrm{Cr}>\mathrm{Cd}$, with maximum concentrations of $0.086,0.073,0.71,0.068,0.051,0.056$, 0.031 , and $0.024 \mathrm{ppm}$, respectively.

\section{Isolation of heavy metal-resistant bacteria}

During the initial screening process of the Tanjaro River water samples, 200 metal-resistant colonies were observed. After further purification, 39 metal-resistant bacteria that could tolerate heavy metal-containing LB agar were selected for further characterization. These heavy metal-resistant strains included both gram-negative and gram-positive bacteria. Gram staining identified 17 $(43.5 \%)$ isolates as gram-positive, while the other 22 $(56.5 \%)$ were gram-negative. The nearest identities of all bacterial isolates and their gram stain properties are presented in (Table 4).

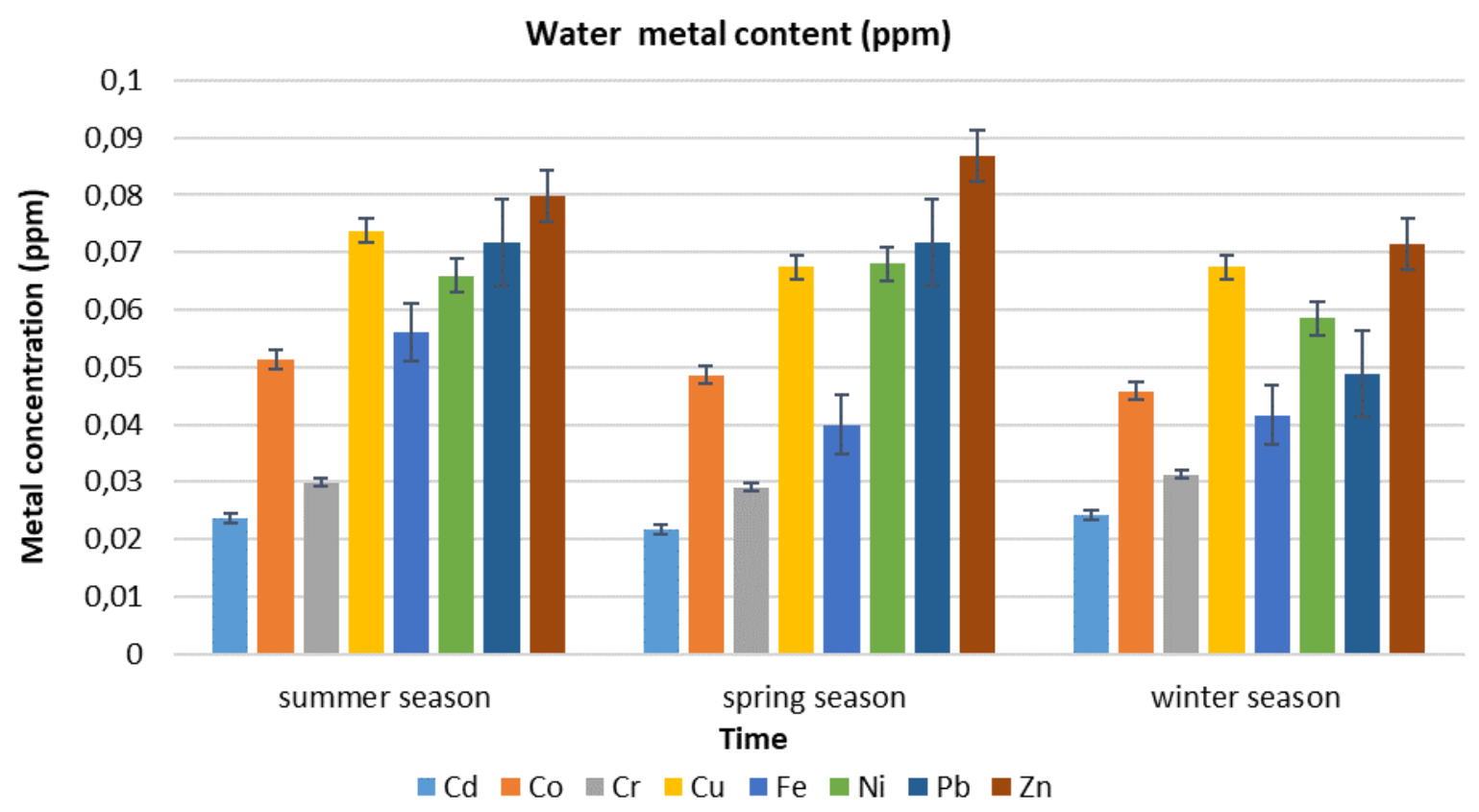

Figure 2. Heavy metal content (ppm) in the water samples 
Table 2. Water samples in situ measured parameters during study period

\begin{tabular}{|c|c|c|c|c|c|c|c|c|c|c|c|c|c|c|c|c|c|c|c|c|c|c|c|c|}
\hline \multirow{2}{*}{$\begin{array}{l}\text { Months/ } \\
\text { sites }\end{array}$} & \multicolumn{6}{|c|}{ Temperature } & \multicolumn{6}{|c|}{ PH } & \multicolumn{6}{|c|}{ EC $\left(\mu{\mathrm{S} . c m^{-1}}^{2}\right)$} & \multicolumn{6}{|c|}{ Total dissolved solids(mg.l $\left.{ }^{-1}\right)$} \\
\hline & 1 & 2 & 3 & 4 & 5 & 6 & 1 & 2 & 3 & 4 & 5 & 6 & 1 & 2 & 3 & 4 & 5 & 6 & 1 & 2 & 3 & 4 & 5 & 6 \\
\hline Jan & 11.9 & 12.1 & 12.1 & 12.3 & 12.5 & 14.3 & 7.32 & 7.3 & 7.34 & 7.33 & 7.18 & 7.16 & 583 & 580 & 576 & 570 & 570 & 589 & 291 & 290 & 289 & 278 & 286 & 295 \\
\hline Feb & 15.4 & 15.4 & 16.1 & 16.6 & 15.8 & 15 & 7.28 & 7.28 & 7.3 & 7.2 & 7.35 & 7.35 & 560 & 562 & 556 & 556 & 555 & 525 & 280 & 280 & 278 & 278 & 277 & 268 \\
\hline Apr & 19 & 19.9 & 19.9 & 20.3 & 2.3 & 20.6 & 6.88 & 6.94 & 7.01 & 7.14 & 7.23 & 7.22 & 555 & 674 & 740 & 804 & 779 & 601 & 272 & 330 & 364 & 397 & 390 & 300 \\
\hline May & 21.1 & 21.1 & 21.5 & 21.4 & 22.2 & 21.4 & 7.2 & 7.2 & 7.27 & 7.36 & 7.31 & 7.27 & 563 & 563 & 567 & 660 & 568 & 559 & 281 & 281 & 283 & 330 & 384 & 279 \\
\hline Jun & 26.6 & 27.3 & 27.9 & 28 & 27.8 & 25.7 & 7.4 & 7.2 & 7.19 & 7.1 & 6.9 & 7 & 687 & 678 & 657 & 673 & 686 & 693 & 344 & 339 & 328 & 336 & 339 & 348 \\
\hline Jul & 30 & 30 & 30.1 & 29 & 29 & 30 & 7.1 & 7.04 & 6.8 & 6.7 & 6.7 & 6.5 & 699 & 706 & 702 & 700 & 704 & 706 & 350 & 350 & 34 & 350 & 351 & 350 \\
\hline Aug & 31 & 30 & 30 & 30 & 30.6 & 31 & 8.39 & 8.64 & 8.54 & 8.35 & 8.26 & 8.39 & 745 & 571 & 748 & 750 & 739 & 745 & 372 & 375 & 374 & 370 & 370 & 372 \\
\hline Sep & 27.9 & 27 & 36 & 27.5 & 28.2 & 28 & 6.8 & 6.9 & 6.7 & 6.3 & 6.8 & 6.6 & 928 & 922 & 796 & 794 & 794 & 775 & 464 & 461 & 398 & 397 & 397 & 400 \\
\hline Oct & 24 & 24 & 29 & 24 & 25 & 24 & 7.1 & 7.5 & 6.5 & 6.3 & 6.5 & 6.1 & 796 & 794 & 794 & 794 & 922 & 928 & 398 & 397 & 397 & 396 & 461 & 464 \\
\hline Mean & 22.9 & 23.03 & 23.3 & 23.3 & 23.3 & 23.3 & 7.28 & 7.33 & 7.18 & 7.08 & 7.14 & 7.07 & 679.5 & 692.5 & 681.7 & 699.8 & 701 & 680.1 & 339.1 & 345 & 339.6 & 348 & 361 & 341.7 \\
\hline \pm SD & \pm & \pm & \pm & \pm & \pm & \pm & \pm & \pm & \pm & \pm & \pm & \pm & \pm & \pm & \pm & \pm & \pm & \pm & \pm & \pm & \pm & \pm & \pm & \pm \\
\hline & 1.5 & 1.4 & 1.45 & 1.38 & 1.43 & 1.38 & 0.1 & 0.12 & 0.13 & 0.14 & 0.11 & 0.14 & 29.4 & 27.1 & 22 & 21.4 & 28.2 & 29 & 14.9 & 13.6 & 10.9 & 10.8 & 13 & 14.6 \\
\hline
\end{tabular}

Table 3. Water samples laboratory-measured parameters during study period

\begin{tabular}{|c|c|c|c|c|c|c|c|c|c|c|c|c|c|c|c|c|c|c|}
\hline & \multicolumn{7}{|c|}{ Total hardness $\left(\mathrm{mg} . \mathrm{l}^{-1}\right)$} & \multicolumn{5}{|c|}{ Alkalinity $\left(\mathrm{mg} . \mathrm{l}^{-1}\right)$} & \multicolumn{6}{|c|}{ Chloride $\left(\mathrm{mg} . \mathrm{l}^{-1}\right)$} \\
\hline & 1 & 2 & 3 & 4 & 5 & 6 & 1 & 2 & 3 & 4 & 5 & 6 & 1 & 2 & 3 & 4 & 5 & 6 \\
\hline Jan & 269 & 282 & 304 & 305 & 285 & 332 & 126 & 122 & 124 & 140 & 126 & 181 & 29.9 & 31 & 31.6 & 34 & 35.5 & 42.5 \\
\hline Feb & 300 & 258 & 278 & 264 & 248 & 257.5 & 127 & 158 & 156 & 129 & 156 & 138 & 21.6 & 17.7 & 16.6 & 17.3 & 17 & 21.9 \\
\hline Apr & 294 & 300 & 264 & 306 & 232 & 266 & 229 & 260 & 225 & 245 & 231 & 218 & 27.5 & 36.5 & 29.4 & 13.2 & 21.5 & 25.7 \\
\hline May & 415 & 355 & 430 & 410 & 485 & 380 & 207 & 208 & 197 & 209 & 184 & 216.2 & 24.4 & 26.1 & 29 & 47.2 & 26.1 & 43.9 \\
\hline Jun & 430 & 485 & 310 & 410 & 391 & 390 & 235.2 & 228.9 & 203.5 & 227.3 & 209.8 & 241.6 & 57.4 & 58.1 & 53.88 & 48.2 & 51.04 & 59.5 \\
\hline Jul & 322 & 342 & 310 & 371 & 380 & 308 & 205.1 & 198.7 & 201.9 & 208.2 & 186 & 203.5 & 57.4 & 58.1 & 53.8 & 48.2 & 51 & 56.7 \\
\hline Aug & 364 & 314 & 280 & 326 & 354 & 360 & 241.6 & 197.1 & 219.4 & 240.09 & 251.2 & 238.5 & 75.8 & 64.5 & 62.3 & 67.4 & 65.9 & 75.1 \\
\hline Sep & 354 & 368 & 358 & 338 & 322 & 352 & 303.6 & 255.9 & 248 & 249.6 & 287.2 & 320 & 73.7 & 76.5 & 78.6 & 76.5 & 72.3 & 72 \\
\hline Oct & 356 & 340 & 324 & 345 & 364 & 320 & 254.4 & 244.8 & 254.4 & 262.5 & 298.9 & 324.3 & 77.9 & 76.5 & 73.7 & 74 & 75.1 & 72.3 \\
\hline Mean \pm SD & 344.8 & 338.2 & 317.8 & 341.6 & 340.1 & 329.5 & 214.3 & 213.4 & 204.1 & 212.1 & 210.2 & 231.2 & 49.5 & 49.5 & 47.7 & 47.2 & 45.9 & 52.2 \\
\hline & $\begin{array}{c} \pm \\
54.5\end{array}$ & $\stackrel{ \pm}{63.8}$ & $\begin{array}{c} \pm \\
49.7\end{array}$ & $\begin{array}{c} \pm \\
48.07\end{array}$ & $\begin{array}{c} \pm \\
76.3\end{array}$ & $\begin{array}{c} \pm \\
45.4\end{array}$ & $\begin{array}{c} \pm \\
60.1\end{array}$ & $\begin{array}{c} \pm \\
52.6\end{array}$ & $\begin{array}{c} \pm \\
41.6\end{array}$ & $\begin{array}{c} \pm \\
46.2\end{array}$ & $\begin{array}{c} \pm \\
51.9\end{array}$ & $\begin{array}{c} \pm \\
58.4\end{array}$ & $\begin{array}{c} \pm \\
23.04\end{array}$ & $\begin{array}{c} \pm \\
21.3\end{array}$ & $\begin{array}{c} \pm \\
21.4\end{array}$ & $\begin{array}{c} \pm \\
22.4\end{array}$ & $\begin{array}{c} \pm \\
21.7\end{array}$ & $\begin{array}{c} \pm \\
19.3\end{array}$ \\
\hline
\end{tabular}


Table 4. 16S rRNA identity of bacterial isolates

\begin{tabular}{|c|c|c|c|}
\hline Code & Bacterial isolates & $\begin{array}{c}\text { GenBank } \\
\text { acc. no. }\end{array}$ & $\begin{array}{c}\text { Gram } \\
\text { reaction }\end{array}$ \\
\hline 1. & Bacillus pumilus strain BP01L & MZ447081 & + \\
\hline 2. & Enterococcus faecalis-EF02I & MZ447082 & + \\
\hline 3. & Microbacterium maritypicum-MM03F & MZ447083 & + \\
\hline 4. & Bacillus cereus-BC04I & MZ447084 & + \\
\hline 5. & Enterococcus gallinarum-EG05I & MZ447085 & + \\
\hline 6. & Proteus vulgaris-PV06T & MZ447086 & - \\
\hline 7. & Providencia vermicola-PV07T & MZ447087 & - \\
\hline 8. & Escherichia fergusonii-EF08T & MZ447088 & - \\
\hline 9. & Klebsiella quasipneumoniae-KQ09T & MZ447089 & - \\
\hline 10. & Acinetobacter junii-AJ10T & MZ447090 & - \\
\hline 11. & Morganella morganii-MM11T & MZ447091 & - \\
\hline 12. & Pseudomonas aeruginosa-PA12T & MZ447092 & - \\
\hline 13. & Pseudomonas.aeruginosa-PA13T & MZ447093 & - \\
\hline 14. & Bacillus cereus-BC14L & MZ447094 & + \\
\hline 15. & Leucobacter chromiiresistens-LC15T & MZ447095 & + \\
\hline 16. & Bacillus safensis-BS16L & MZ447096 & + \\
\hline 17. & Raoultella planticola-RP17T & MZ447097 & - \\
\hline 18. & Proteus mirabilis-PM18T & MZ447098 & - \\
\hline 19. & Lysinibacillus fusiformis-LF19T & MZ447099 & + \\
\hline 20. & Bacillus tropicus-BT20L & MZ447100 & + \\
\hline 21. & Bacillus zhangzhouensis-BZH21L & MZ447101 & + \\
\hline 22. & Bacillus zhangzhouensis-BZH22L & MZ447102 & + \\
\hline 23. & Bacillus safensis-BS23L & MZ447103 & + \\
\hline 24. & Acinetobacter junii-AJ24T & MZ447104 & - \\
\hline 25. & Morganella morganii-MM25T & MZ447105 & + \\
\hline 26. & Pseudomonas taiwanensis-PT26T & MZ447106 & - \\
\hline 27. & Pseudomonas plecoglossicida-PP27T & MZ447107 & - \\
\hline 28. & Enterococcus faecalis-EF28I & MZ447108 & - \\
\hline 29. & Enterobacter tabaci-ET29T & MZ447109 & - \\
\hline 30. & Enterobacter tabaci-ET30T & MZ447110 & - \\
\hline 31. & Aeromonas caviae-AC31T & MZ447111 & - \\
\hline 32. & Microbacterium oxidanse-MO32I & MZ447112 & + \\
\hline 33. & Pseudomonas aeruginosa-PA33T & MZ447113 & - \\
\hline 34. & Proteus mirabilis-PM34T & MZ447114 & - \\
\hline 35. & Enterobacter tabaci-ET35 & MZ447115 & - \\
\hline 36. & Aeromonas caviae-AC36T & MZ447116 & - \\
\hline 37. & Proteus vulgaris-PV37T & MZ447117 & - \\
\hline 38. & Bacillus zhangzhouensis-BZH38L & MZ447118 & + \\
\hline 39. & Bacillus safensis-BS39L & MZ447119 & + \\
\hline
\end{tabular}

\section{Molecular characterization of metal-resistant isolates}

Amplification of the 16S rRNA genes was performed using universal primers. The 16S rRNA gene sequence of each isolated strain (those which showed metal resistance) were searched in the National Center for Biotechnology Information (NCBI) database. Blast queries revealed that the strains belonged to the Bacillaceae, Moraxellaceae, Morganellaceae, Enterococcaceae, Microbacteriaceae, Enterobacteriaceae, Pseudomonadaceae, and Aeromonadaceae families.

\section{Assessment of heavy metal tolerance}

The bacteria were evaluated for their ability to resist different concentrations of heavy metals. The MTCs of the bacterial isolates against the tested metal salts are summarized in (Table 5). The MTCs varied from 10-250 $\mathrm{ppm}$. Among the heavy metals, cadmium and copper were highly toxic, while, lead and iron were less toxic to all strains. All of the detected isolates were resistant to selected metals, but they exhibited different levels of resistance. The isolates presented a diverse metal-resistant phenotype and were resistant to one or more metal ions. $B$. safensis-BS16L and L.chromiiresistens-C15T were respectively able to tolerate high $\mathrm{Cd}(80,90), \mathrm{Pb}(250$, $160), \mathrm{Cr}(210,100), \mathrm{Ni}(110,90)$ and $\mathrm{Co}(160,170)$ concentrations (all values in $\mathrm{ppm}$ ). In addition, $P$. mirabilis-PM18T could tolerate $90 \mathrm{ppm} \mathrm{Cd}$. The highest levels of resistance were detected for $\mathrm{Pb}$ and $\mathrm{Fe}$ in all isolates. Although $\mathrm{Zn}$ had the highest concentration in the water samples, most of the isolates showed low levels of Zn tolerance.

\section{Heavy metal removal efficacy}

The ability of the bacterial isolates to remove heavy metals from the medium was measured by ICP-OES. $P$. plecoglossicida-PP27T and E. gallinarum-EG05I removed the highest amount of cadmium $(41.9 \%$ and $41.1 \%$, respectively), as shown in (Figure 4). B. safensis-BS16L removed the highest amount of $\mathrm{Pb}, \mathrm{Cr}, \mathrm{Ni}, \mathrm{Fe}$, and $\mathrm{Co}$ $(55.4 \%, 53.1 \%, 53.7 \%, 47.7 \%$, and $61.4 \%$, respectively) (Figures 3, 4, and 5). Enterobacter tabaci-ET29T removed the highest amount of $\mathrm{Cu}(55.8 \%)$. Among the metals, zinc had the lowest amount of removal, which did not exceed $29.3 \%$ (Figure 4).

\section{Discussion}

\section{Physicochemical characteristics of the water samples}

We used a simple portable water quality tester to perform in situ analysis of the water temperature, $\mathrm{pH}, \mathrm{EC}$, and TDS. The water temperature is an important factor that affects the concentrations of several inorganic chemical contaminants (WHO 2011) and directly or indirectly influences the biological species that can survive in a given aquatic environment (Iram et al. 2013). No abnormal water temperatures were recorded for the water samples. Statistical analysis indicated that there was only significant variation among different months in the studied area $(\mathrm{P}<0.05)$. It appears that the coldest temperature value was recorded in January, while the hottest one was during August, similar temperature ranges have been previously documented by (Mustafa 2006).

The water $\mathrm{pH}$ is important in assessing water quality because it affects other chemical parameters such as solubility and metal toxicity (Al-Taei et al. 2020). The pH range of surface water according to (WHO 2011) is 6.5-8.5 where keeps most trace elements immobilized. Most of the samples had $\mathrm{pH}$ values within this range except samples from $\mathrm{S} 2$ and $\mathrm{S} 6$. The $\mathrm{pH}$ was highest in the sample from $\mathrm{S} 2$ (8.64), which is slightly higher than the WHO recommended range for surface water. The $\mathrm{pH}$ values of samples collected in August were higher than in the other months, likely because of reduced rainfall and river volume during this time (Besharati et al. 2018), while Mohsenpour et al. (2021) suggested that the elevation in $\mathrm{pH}$ level could result from an increase in both photosynthetic activity and sewage disposal with high detergent concentrations. 
Table 5. Heavy metal maximum tolerable concentrations (MTCs) of the bacteria isolates

\begin{tabular}{|c|c|c|c|c|c|c|c|c|c|}
\hline \multirow{2}{*}{ Code } & \multirow{2}{*}{ Bacterial isolates } & \multicolumn{8}{|c|}{ Metal concentration in ppm } \\
\hline & & Cd & $\mathbf{P b}$ & $\mathbf{C u}$ & $\mathrm{Cr}$ & $\mathbf{N i}$ & $\mathrm{Zn}$ & Co & $\mathbf{F e}$ \\
\hline 1 & Bacillus pumilus strain BP01L & 30 & 120 & 40 & 60 & 70 & 50 & 60 & 170 \\
\hline 2 & Enterococcus faecalis-EF02I & 30 & 140 & 30 & 60 & 70 & 30 & 60 & 170 \\
\hline 3 & Microbacterium maritypicum-MM03F & 20 & 130 & 40 & 60 & 70 & 40 & 60 & 150 \\
\hline 4 & Bacillus cereus-BC04I & 30 & 130 & 40 & 60 & 70 & 40 & 60 & 150 \\
\hline 5 & Enterococcus gallinarum-EG05I & 40 & 130 & 40 & 40 & 70 & 40 & 60 & 160 \\
\hline 6 & Proteus vulgaris-PV06T & 50 & 100 & 10 & 80 & 40 & 20 & 30 & 150 \\
\hline 7 & Providencia vermicola-PV07T & 30 & 140 & 40 & 60 & 80 & 50 & 110 & 180 \\
\hline 8 & Escherichia fergusonii-EF08T & 30 & 140 & 60 & 60 & 80 & 60 & 60 & 170 \\
\hline 9 & Klebsiella quasipneumoniae-KQ09T & 30 & 130 & 40 & 40 & 70 & 50 & 130 & 160 \\
\hline 10 & Acinetobacter junii-AJ10T & 30 & 140 & 50 & 50 & 70 & 60 & 110 & 160 \\
\hline 11 & Morganella morganii-MM11T & 30 & 140 & 30 & 50 & 60 & 40 & 60 & 160 \\
\hline 12 & Pseudomonas aeruginosa-PA12T & 40 & 130 & 40 & 60 & 70 & 40 & 60 & 140 \\
\hline 13 & Pseudomonas.aeruginosa-PA13T & 50 & 130 & 40 & 30 & 70 & 60 & 60 & 160 \\
\hline 14 & Bacillus cereus-BC14L & 20 & 130 & 40 & 60 & 70 & 30 & 20 & 140 \\
\hline 15 & Leucobacter chromiiresistens-LC15T & 90 & 160 & 50 & 100 & 90 & 50 & 170 & 150 \\
\hline 16 & Bacillus safensis-BS16L & 80 & 250 & 80 & 210 & 110 & 60 & 160 & 250 \\
\hline 17 & Raoultella planticola-RP17T & 50 & 130 & 40 & 40 & 70 & 50 & 50 & 150 \\
\hline 18 & Proteus mirabilis-PM18T & 90 & 130 & 40 & 40 & 70 & 50 & 60 & 150 \\
\hline 19 & Lysinibacillus fusiformis-LF19T & 30 & 130 & 40 & 40 & 70 & 30 & 60 & 150 \\
\hline 20 & Bacillus tropicus-BT20L & 30 & 130 & 40 & 30 & 70 & 40 & 30 & 140 \\
\hline 21 & Bacillus zhangzhouensis-BZH21L & 20 & 120 & 30 & 30 & 70 & 30 & 20 & 150 \\
\hline 22 & Bacillus zhangzhouensis-BZH22L & 30 & 120 & 20 & 30 & 60 & 20 & 10 & 150 \\
\hline 23 & Bacillus safensis-BS23L & 40 & 120 & 20 & 30 & 50 & 30 & 40 & 140 \\
\hline 24 & Acinetobacter junii-AJ24T & 40 & 130 & 40 & 30 & 70 & 10 & 10 & 150 \\
\hline 25 & Morganella morganii-MM25T & 40 & 120 & 40 & 30 & 80 & 10 & 80 & 140 \\
\hline 26 & Pseudomonas taiwanensis-PT26T & 40 & 120 & 30 & 100 & 90 & 10 & 80 & 115 \\
\hline 27 & Pseudomonas plecoglossicida-PР27T & 30 & 130 & 40 & 30 & 70 & 50 & 50 & 150 \\
\hline 28 & Enterococcus faecalis-EF28I & 50 & 120 & 20 & 30 & 40 & 10 & 80 & 140 \\
\hline 29 & Enterobacter tabaci-ET29T & 50 & 130 & 70 & 160 & 90 & 60 & 90 & 260 \\
\hline 30 & Enterobacter tabaci-ET30T & 40 & 130 & 60 & 140 & 60 & 60 & 70 & 170 \\
\hline 31 & Aeromonas caviae-AC $31 \mathrm{~T}$ & 50 & 120 & 30 & 100 & 60 & 20 & 50 & 140 \\
\hline 32 & Microbacterium oxidanse-MO32I & 30 & 120 & 40 & 30 & 70 & 30 & 30 & 140 \\
\hline 33 & Pseudomonas aeruginosa-PA33T & 20 & 130 & 40 & 40 & 70 & 50 & 70 & 160 \\
\hline 34 & Proteus mirabilis-PM34T & 40 & 150 & 70 & 80 & 90 & 50 & 30 & 160 \\
\hline 35 & Enterobacter tabaci-ET35 & 40 & 140 & 50 & 60 & 80 & 60 & 30 & 170 \\
\hline 36 & Aeromonas caviae-AC $36 \mathrm{~T}$ & 40 & 150 & 60 & 60 & 80 & 50 & 70 & 150 \\
\hline 37 & Proteus vulgaris-PV37T & 40 & 120 & 30 & 30 & 60 & 30 & 40 & 150 \\
\hline 38 & Bacillus zhangzhouensis-BZH38L & 20 & 120 & 20 & 50 & 80 & 50 & 30 & 150 \\
\hline 39 & Bacillus safensis-BS39L & 20 & 150 & 60 & 70 & 90 & 50 & 70 & 170 \\
\hline
\end{tabular}

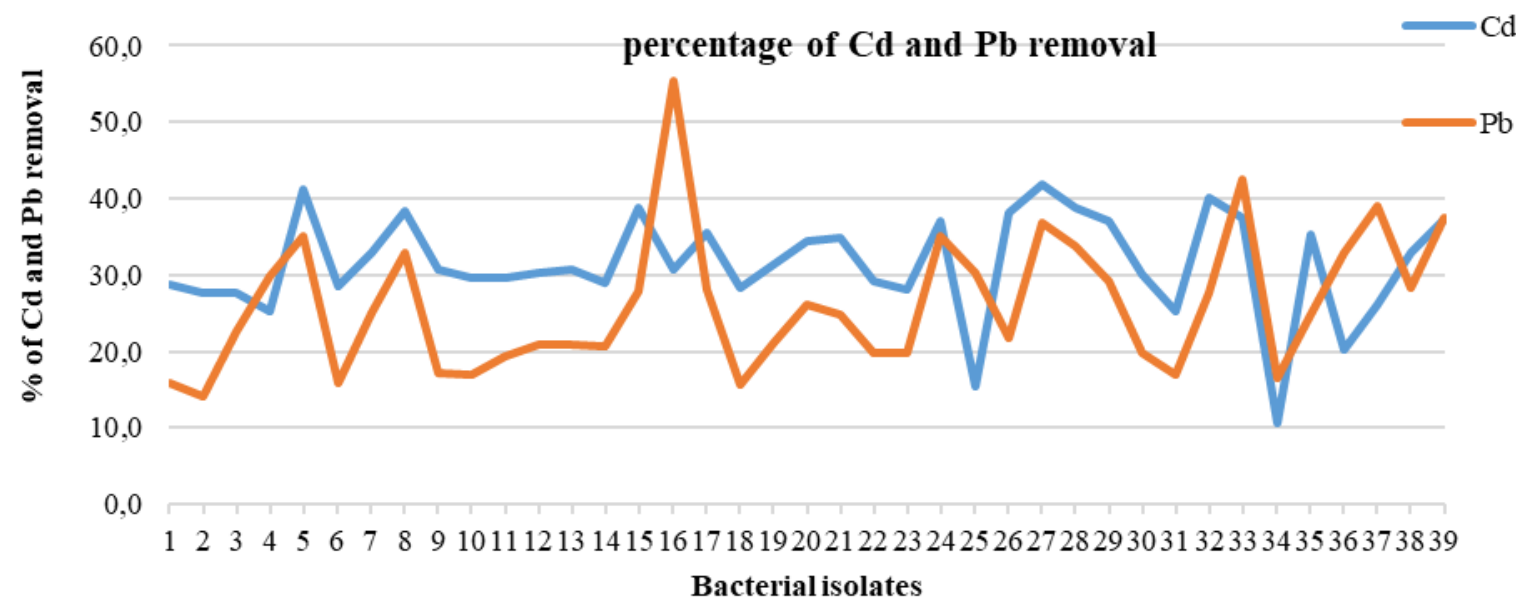

Figure 3. Percentage of cadmium and lead removed by isolated bacteria 
The ideal $\mathrm{pH}$ for bacterial growth is usually between 6.5 and 7.5. The electrical conductivity started from 525 $\mu \mathrm{S} . \mathrm{cm}^{-1}$ at $25^{\circ} \mathrm{C}$ in February which was relatively lower than that recorded by (Rashid 2010) but higher than the results of (Mustafa 2006), then increased as the study period progressed, reaching $928 \mu \mathrm{S} . \mathrm{cm}^{-1}$ at $25^{\circ} \mathrm{C}$ in September. This may have been due to the changing climate and the increasing temperature, as found by (AlAmeri 2011). The conductivity is highly dependent on the amount of dissolved solids (such as salt), particulate mobility, and temperature (APHA 2005), and this was confirmed by observing the maximum level of dissolved solids in September, the presence of high concentration of dissolved solid elements could affect water density, freshwater species' osmoregulation, reduces the solubility of gases, and limits the use of water for drinking and irrigation (Azeez 2021), as the water from Tanjaro River is used for irrigation, much of the water will be taken up by the crop and transpired; proportion of the salts will be left behind in the soil and lead to build-up of salts in the root zone of the crop (Rashid 2010). Dissolved calcium and, to a lesser degree, magnesium, which is expressed as an equal amount of calcium carbonate, causes water hardness (WHO 2011). Tanjaro River has hard water according to WHO guidelines, our recorded data exceeded the $200 \mathrm{mg} . \mathrm{l}^{-1}$ WHO maximum recommendation. (Ebrahimpour et al. 2010) stated that water hardness affects the solubility and toxicity of heavy metals. Metals are more toxic in soft water than in hard water because their solubility increases with the decreasing of water hardness, heavy metal concentration obtained by (Al-Asadi et al. 2020) is lower than those obtained in our study with higher levels of calcium and magnesium hardness, In our study, the heavy metal concentrations decreased in spring, during which higher levels of hardness were recorded and this confirms the finding of (Aziz et al. 2012) that shows the decrease in metal toxicity with the increasing of water hardness. Water samples had alkalinity values higher than the acceptable level for freshwater $200 \mathrm{mg} . \mathrm{l}^{-1}$ (WHO 2006). Throughout the study period, the chloride concentrations were less than the maximum WHO recommended value, The amount of chloride in the water possibly results from the excessive use of chloride as a disinfectant in various water purification and the industrial wastes discharged into the river (Mustafa 2006; Rashid 2010).

\section{Metal content of the water samples}

The Tanjaro River is contaminated with heavy metals, wastewater effluent and municipal sewage outlets of the areas and industrial area, Albisaka, Qalawa, Wluba, ShekhAbbas and Bakrajo boxes are discharged directly to
Tanjaro River without any pretreatment that leading to heavy metal accumulation (Majid et al. 2018).

Several variations in heavy metal concentrations were observed between sampling sites. The hydrological formation of the sampling site had a notable impact on water quality. The statistical analysis also revealed that changes in the metal concentrations were primarily influenced by the time of year (Saran et al. 2012). Cd, Pb, and $\mathrm{Ni}$ were present in high concentrations in the water samples, while $\mathrm{Co}, \mathrm{Cu}, \mathrm{Cr}, \mathrm{Fe}$ and $\mathrm{Zn}$ were found within the normal range of (EPA 2003; WHO 2011). The results were lower than those observed by (Mustafa 2006; Rashid 2010) but higher than those obtained by (Rasheed and HamaKarim 2017) at the same river, and those obtained by (Hamdan 2010; Al-Abbawy et al. 2021) at both ShattAlarab and Al-Hawizeh Marsh, southern of Iraq, the low observation may be attributed to the fact that most factories stopped operating during their study period. The continuous use of contaminated water for irrigation may cause the accumulation of metals to concentrations that are toxic for plants and animals (Iram et al. 2013).

\section{Isolation of heavy metal-resistant bacteria}

Several previous studies indicate that the toxic effect of metal ions exert selection pressure on bacteria whereby those that are resistant to these metals survive (Mustapha and Halimoon 2015). Overall, 39 bacterial strains were able to grow on heavy metal-spiked L.B agar. Gram staining revealed the presence of both gram-positive and gramnegative bacteria. This indicates that both types of bacteria are involved in metal removal; however, a predominance of gram-negative bacteria strains was found among the heavy metal-tolerant strains isolated from the Tanjaro River for all studied metals, which is in accordance with previous findings of (Bennisse et al. 2004; Irawati et al. 2017), which found that the majority of isolates subjected to selection pressures in the presence of toxic compounds were gram-negative. However, another study found different results (Silva et al. 2012). It has been proposed that the cell wall of gram-negative bacteria is an effective barrier against toxic metals and that the cell wall's surface structures interact with metal ions, resulting in their detoxification. By contrast, the peptidoglycan cell wall of gram-positive bacteria absorbs contaminants, overloading the bacterial cell and destroying it (Alegbeleye et al. 2017). The majority of the isolated bacteria belonged to the Bacillaceae and Enterobacteriaceae families (11 species for each family), which is similar to the results obtained by (Besharati et al. 2018; Cai et al. 2019). However, a predominance of Proteobacteria was reported by (Karelova et al. 2011). 


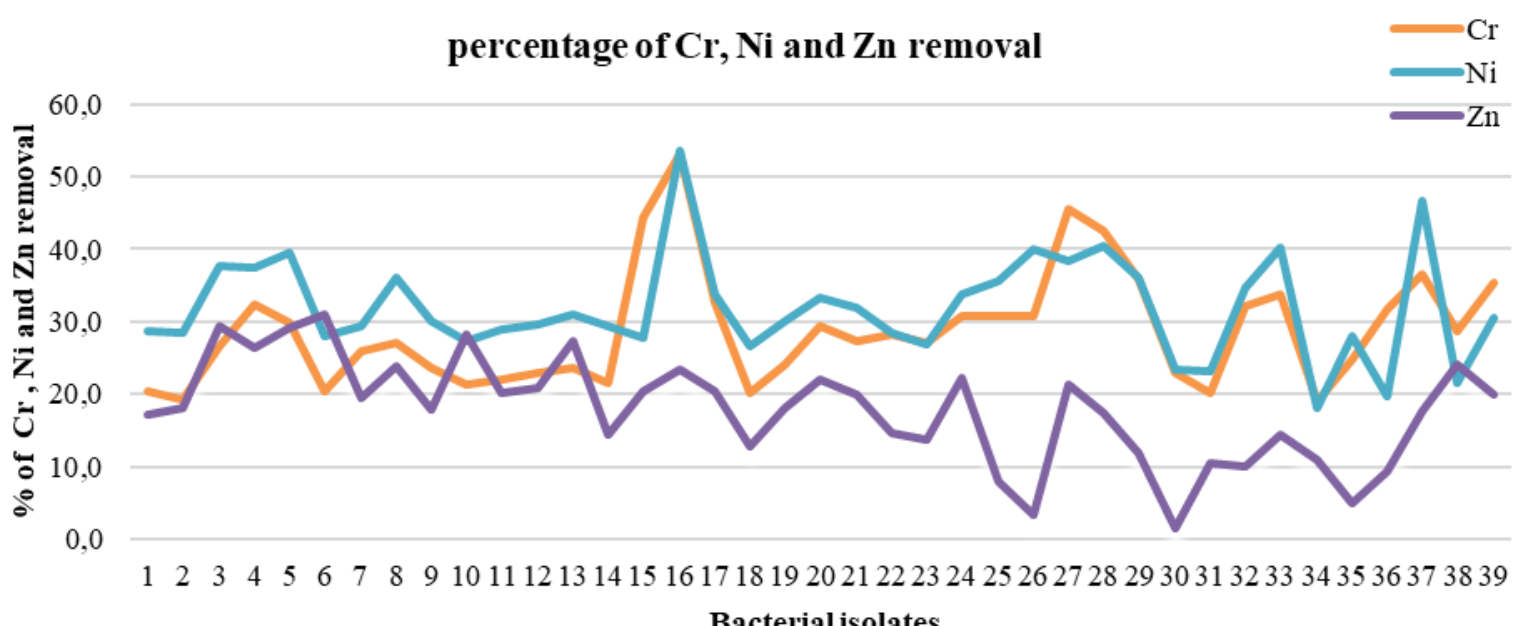

Figure 4. Percentage of chromium, nickel, and zinc removed by isolated bacteria

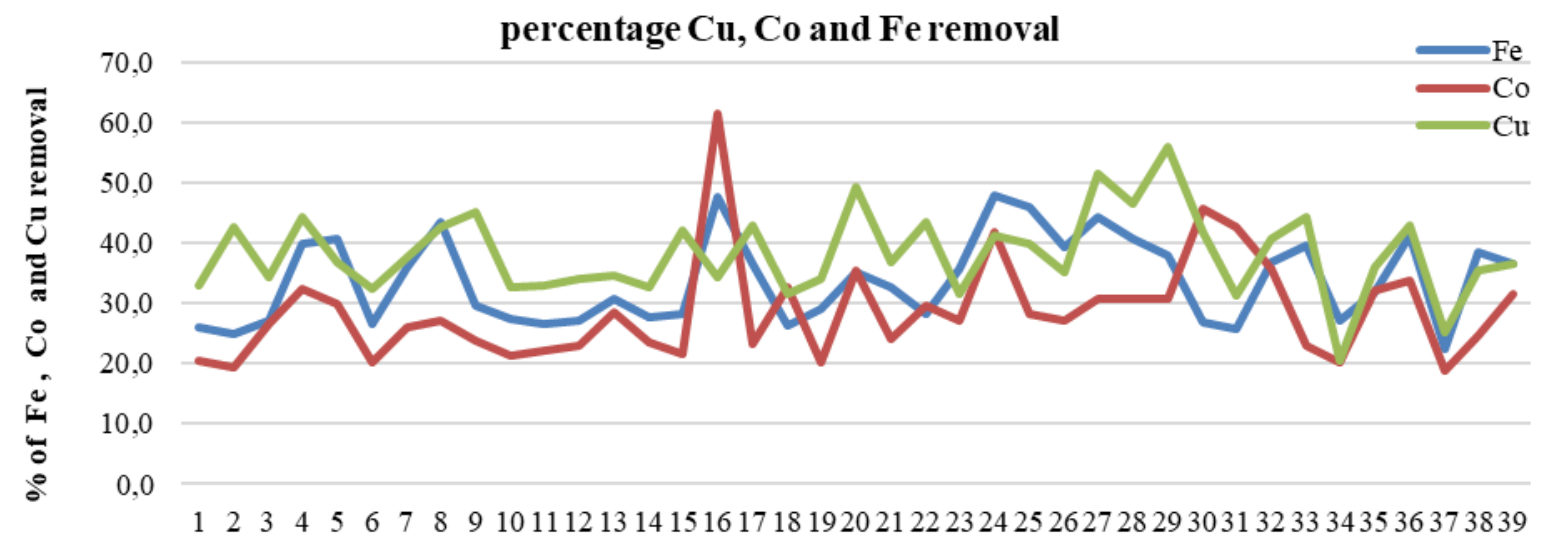

Bacterial isolates

Figure 5. Percentage of iron, cobalt, and copper removed by isolated bacteria

\section{Bacterial tolerance to heavy metal salts}

The maximum tolerable concentrations of heavy metals among the isolates are summarized in (Table 5). The isolated strains showed different patterns of resistance. This variation in metal tolerance might be due to the presence of different tolerance mechanisms (Irawati et al. 2017). $B$. safensis strain NBRC and $L$. chromiiresistens strain JG showed the highest heavy metal tolerance and were resistant to heavy metals in the order of $\mathrm{Pb}>\mathrm{Cr}>\mathrm{Co}>\mathrm{Ni}$; they were also resistant to higher concentrations than those recorded by (Mandal et al. 2020). Among the investigated heavy metals, iron was the least toxic, whereas cadmium, copper, and zinc were highly toxic to all strains. Similar results were found by (Afzal et al. 2017). The isolates identified in the current study were resistant to high levels of $\mathrm{Pb}$ (approximately $250 \mathrm{ppm}$ ). This may be attributed to the site where the water samples were taken being polluted with high levels of lead. Othman (2017) stated that lead is one of the heavy metals of special concern in Iraqi
Kurdistan because of a number of emission sources, including low-quality petrol, widespread use of leaded paints in industry, unsafe disposal of car batteries and other batteries and lead products into water sources, while (Mustafa 2006) revealed that besides the pollution from sewages, Sulaimani oil refinery wastes are the second most significant source of $(\mathrm{pb})$ pollution in Tanjaro river. This high level of $\mathrm{Pb}$ potentially allowing a diverse range of bacteria to adapt to the environment, either through convergent evolution of resistance mechanisms or through plasmid-based transmission of resistance genes. A similar finding was obtained by (Gummersheimer and Giblin 2003). Resistance mechanisms can be encoded in plasmid genes, facilitating the transfer of toxic metal resistance factors from one cell to another. Because heavy metals cannot be degraded or destroyed, their introduction into the environment in various forms can cause significant changes in microbial communities and their activities, compromising their ability to survive (Samanta et al. 2012). 
High bacterial metal tolerance is an important factor to be considered for the remediation of heavy metals because it is directly related to the survival and growth of bacteria in metal-contaminated environments (Kang et al. 2016). Generally, the ability of microbes to grow in environments with high metal concentrations is linked to several complex resistance mechanisms and environmental factors, such as microbial surface sorption, enzymatic transformation, precipitation by oxidation/reduction reactions, and biosynthesis of metal-binding proteins or extracellular polymers (Srinath et al. 2002).

\section{Heavy metal removal efficacy}

Some microorganisms have evolved detoxification mechanisms to counter the toxic effects of heavy metals (Mustapha and Halimoon 2015). Many microorganisms produce a variety of metabolic enzymes that can safely remove contaminants. This can be achieved either by directly destroying the contaminant or transforming it into a less toxic intermediate (Saran et al. 2012). In this study, we have demonstrated the potential for microbes to be used to remediate sites with metal contamination by removing metals from the contaminated medium. Several metaltolerant bacterial species were able to remove heavy metals at various concentrations. B. safensis and $L$. chromiiresistens were found to tolerate the highest concentrations of $\mathrm{Cd}, \mathrm{Pb}, \mathrm{Cu}$, and $\mathrm{Co}$, but they were less effective in the bioremediation of cadmium. The highest concentrations of cadmium were removed by $P$. plecoglossicida-PP27T and E. gallinarum-EG05I. These results are similar to those of (Yamina et al. 2012). $B$. safensis was able to remove $55.4 \%, 53.1 \%, 53.7 \%, 47.7 \%$, and $61.4 \%$ of the $\mathrm{Pb}, \mathrm{Cr}, \mathrm{Ni}, \mathrm{Fe}$, and $\mathrm{Co}$, respectively. However, a previous study done by (Afzal et al. 2017) found that $B$. cereus was the most efficacious strain in terms of metal resistance and metal removal capacity.

Overall, our results showed that the concentrations of cobalt, chromium, copper, iron and zinc in Tanjaro River were all below the allowable limits, in contrast, cadmium, lead and nickel were above the permissible limits set by WHO that are resulting from the impact of sewage and industrial wastewater that directly discharge into the river. Indigenous bacteria could provide new information about the diversity of the species, as well as their role in removing heavy metal from the contaminated area. $B$. safensis and L. chromiiresistens show considerable tolerance ability against studied heavy metals with maximum resistance for lead ions. Remarkably, B. safensis has been shown to remove $\mathrm{Pb}, \mathrm{Cr}, \mathrm{Ni}, \mathrm{Fe}$ and $\mathrm{Co}$, but higher concentration of $\mathrm{Cd}$ was removed from the medium by $P$. plecoglossicida and E. gallinarum.

\section{ACKNOWLEDGEMENTS}

The authors are highly thankful to both University of Sulaimani, and Charmo University-Charmo Center for Research and Training, Kurdistan Region, F.R. Iraq for providing all the available facilities to perform this study.

\section{REFERENCES}

Afzal A, Rasool M, Waseem M, Aslam B. 2017. Assessment of heavy metal tolerance and biosorptive potential of Klebsiella variicola isolated from industrial effluents. AMB Expr 7 (1). DOI: 10.1186/s13568-017-0482-2.

Aktan Y, Tan S, Icgen B. 2013. Characterization of lead-resistant river isolates Enterococcus faecalis and assessment of its multiple metal and antibiotic resistance. Environ Monit Assess 185 (6): 5285-5293. DOI: 10.1007/s10661-012-2945$\mathrm{x}$.

Al-Abbawy DA, Al-Thahaibawi BM, Al-Mayaly IKA, Younis KH. 2021. Assessment of some heavy metals in various aquatic plants of Al-Hawizeh Marsh, Southern of Iraq. Biodiversitas 22 (1): 338-345. DOI: 10.13057/biodiv/d220141

Al-Ameri MA. 2011. Soil and Plant Pollution with Some Heavy Metals Caused by Al-Daura Refinery Emissions on the Surrounded Region. [Thesis]. Univ of Technology, Bagdad.

Al-Asadi SA, Al-Qurnawi W, Al Hawash B, Ghalib HB, Alkhlifa NHA. 2020. Water quality and impacting factors on heavy metals levels in Shatt Al - Arab River, Basra, Iraq. Appl Water Sci 10 (5): 1-15. DOI: 10.1007/s13201-020-01196-1.

Alegbeleye O, Opeolu B, Jackson V. 2017. Bioremediation of polycyclic aromatic hydrocarbon (PAH) compounds: (acenaphthene and fluorene) in water using indigenous bacterial species isolated from the Diep and Plankenburg rivers, Western Cape, South Africa. Braz J Microbiol 48 (2): 314-325. DOI: 10.1016/j.bjm.2016.07.027.

Al-Taei NH, Al-mamoori AMJ, Al-hmoud N. 2020. Estimation of physicochemical parameters and antibiotics resistance patterns in Almamierh treatment plant in Babylon Province, Iraq. Eurasia J Biosci 14: 2989-2996.

APHA (American Public Health Association). 2005. Standard Methods for the Examination of Water and Wastewater. 21th ed. American Public Health Association/American Water Works Association/Water Environment Federation, Washington DC.

Azeez NM. 2021. Bioaccumulation and phytoremediation of some heavy metals $(\mathrm{Mn}, \mathrm{Cu}, \mathrm{Zn}$ and $\mathrm{Pb}$ ) by bladderwort and duckweed. Biodiversitas 22 (5): 2993-2998. DOI: 10.13057/biodiv/d220564

Aziz N, Sabah S. 2012. Pollution of Tanjero River by some heavy metals generated from sewage wastewater and industrial wastewater in Sulaimani District. Kirkuk Univ J Sci Stud 7 (1): 67-84.

Bartram J, Balance R. 1996. Water Quality Monitoring - A Practical Guide to the Design and Implementation of Freshwater Quality Studies and Monitoring Programs. United Nations Environment Program and the World Health Organization, Geneva.

Bennisse R, Labat M, ElAsli A, Brhada F, Chandad F, Lorquin J, Liegbott P, Hibti M, Qatibi A. 2004. Rhizosphere bacterial populations of metallophyte plants in heavy metalcontaminated soils from mining areas in semiarid climate. World J Microbiol Biotechnol 20 (7): 759-766. DOI: 10.1007/s11274-004-5812-2.

Besharati S, Motamedi H, Zallaghi R. 2018. A survey on microbial quality and antibiotic resistance in Karoon River, Khuzestan, Iran. Appl Water Sci 8 (5): 1-6. DOI: 10.1007/s13201-018-0786-7.

Bestawy EE, Helmy S, Hussien H, Fahmy M, and Amer R. 2013. Bioremediation of heavy metal-contaminated effluent using optimized activated sludge bacteria. Appl Water Sci 3 (1): 181-192. DOI: 10.1007/s13201-012-0071-0.

Bui X, Vo T, Ngo H, Guo W, Nguyen T. 2016. Multicriteria assessment of advanced treatment technologies for 
micropollutants removal at large-scale applications. Sci Total Environ 563: 1050-1067. DOI: 10.1016/j.scitotenv.2016.04.191.

Cai X, Zheng X, Zhang D, Iqbal W, Liu C, Yang B, Zhao X, Lu X, MaoY. 2019. Microbial characterization of heavy metal resistant bacterial strains isolated from an electroplating wastewater treatment plant. Ecotoxicol Environ Saf 181: 472480. DOI: 10.1016/j.ecoenv.2019.06.036.

Chaurasia N, Tiwari R, College K, Ravi S, Nagar D. 2011. Effect of industrial effluents and wastes on physico-chemical parameters of river Rapti. Adv Appl Sci Res 2 (5): 207-211.

Ebrahimpour M, Alipour H, Rakhshah S. 2010. Influence of water hardness on acute toxicity of copper and zinc on fish. Toxicol Ind Health 26 (6): 361-365. DOI: $10.1177 / 0748233710369123$.

EPA USA (Environmental Protection Agency). 2003. Guidelines for Ensuring and Maximizing the Quality, Objectivity, Utility, and Integrity of Information Disseminated by the Environmental Protection Agency. EPA, Washington, DC.

El-Shanshoury AR, Sobhy EE, Perihan SA. 2013. Uptake of some heavy metals by metal resistant Enterobacter sp. isolate from Egypt. Afr J Microbiol Res 7 (23): 2875-2884. DOI: 10.5897/ajmr12.1352.

Gummersheimer B, Giblin T. 2003. Identification of lead resistant bacteria from a heavily contaminated site. Bios 74 (2): 48-54.

Hamdan AN. 2020. Assessment of heavy metals pollution in the Shatt Al-Arab River, Basra-Iraq. AIP Conf Proc 2213 (1): 020037. DOI: 10.1063/5.0000300.

Haque MA, Jewel MAS, Sultana MP. 2019. Assessment of physicochemical and bacteriological parameters in surface water of Padma River, Bangladesh. Appl Water Sci 9 (1): 1-8. DOI: 10.1007/s13201-018-0885-5.

Iram S, Kanwal S, Ahmad I, Tabassam T, Suthar V, MahmoodUl-Hassan M. 2013. Assessment of physicochemical parameters of wastewater samples. Environ Monit Assess 185 (3): 2503-2515. DOI: 10.1007/s10661-012-2727-5.

Irawati W, Riak S, Sopiah N, Sulistia S. 2017. Heavy metal tolerance in indigenous bacteria isolated from the industrial sewage in Kemisan River, Tangerang, Banten, Indonesia. $\begin{array}{llll}\text { Biodiversitas } & 18 & \text { (4): } & \text { 1481-1486. }\end{array}$ 10.1r3057/biodiv/d180426.

Jamil A, Ahmed I, Munir S, Akhtar M. 2018. Raoultella and Enterococcus species identified as high chromium and arsenic tolerant bacteria. Biointerface Res Appl Chem 8 (3): 32473251.

Kang C, Kwon Y, So S. 2016. Bioremediation of heavy metals by using bacterial mixtures. Ecol Eng 89: 64-69. DOI: 10.1016/j.ecoleng.2016.01.023.

Kapahi M, Sachdeva S. 2019. Bioremediation options for heavy metal pollution. J Health Pollut 9 (24). DOI: 10.5696/21569614-9.24.191203.

Karelova E, Harichova J, Stojnev T, Pangallo D, Ferianc P. 2011. The isolation of heavy-metal resistant culturable bacteria and resistance determinants from a heavy-metal-contaminated site. Biologia 66 (1): 18-26. DOI: 10.2478/s11756-010-01450 .

Ma J, Wu S, Shekhar NVR, Biswas S, Sahu AK. 2020. Determination of physicochemical parameters and levels of heavy metals in food wastewater with environmental effects. Bioinorg Chem Appl. DOI: 10.1155/2020/8886093.

Majid SN, Khwakaram AIK, Gado CS. 2018. Pollution status evaluation of some heavy metals along some surface water sources by multivariate data analysis at Sulaimani governorate. J Zankoy Sulaimani-Part A 20 (1): 63-80. DOI: 10.17656/jzs. 10642.

Mandal M, Das S, Mandal S. 2020. Principal component analysis exploring the association between antibiotic resistance and heavy metal tolerance of plasmid-bearing sewage wastewater bacteria of clinical relevance. Access Microbiol 2 (3). DOI: 10.1099/acmi.0.000095.

Marzan L, Hossain M, Mina S, Akter Y, Chowdhury A. 2017. Isolation and biochemical characterization of heavy-metal resistant bacteria from tannery effluent in Chittagong city, Bangladesh: Bioremediation viewpoint. Egypt J Aquat Res 43 (1): 65-74. DOI: 10.1016/j.ejar.2016.11.002.

Michalec B, Lenart-Boron A, Cupak A, Wałȩga S. 2014. The evaluation of heavy metal content in water and sediments of small reservoirs in light of various environmental quality regulations. J Environ Sci Health-Part A Toxic/Hazardous Substances Environ Eng 49 (7): 827-832. DOI: 10.1080/10934529.2014.882645.

Mohsenpour SF, Hennige S, Willoughby N, Adeloye A, Gutierrez T. 2021. Integrating micro-algae into wastewater treatment: A review. Sci Total Environ 752: 142168. DOI: 10.1016/j.scitotenv.2020.142168.

Mustafa OM. 2006. Impact of Sewage wastewater on the environment of Tanjero River and its Basin within Sulaimani City /NE Iraq. [Thesis]. Univ. of Sulaimani, Iraq.

Mustapha M, Halimoon N. 2015. Screening and isolation of heavy metal tolerant bacteria in industrial effluent. Procedia Environ Sci 30: 33-37. DOI: 10.1016/j.proenv.2015.10.006.

Ndeddy AR, Babalola O. 2017. Identification and characterization of $\mathrm{Cr}-, \mathrm{Cd}-$, and Ni-tolerant bacteria isolated from mine tailings. Bioremediat J 21 (1): 1-19. DOI: 10.1080/10889868.2017.1282933.

Othman N, Kane T, Mohammed K, Alkaradaghi K, Salih F, Abdullah T, Hamafaraj K. 2017. Environmental health assessment in Sulaymaniyah City and Vicinity. Kurdistan Institution for Strategic Studies and Scientific Research, William Joiner Institute, University of Massachusetts, Boston. DOI: 10.13140/RG.2.2.12898.12483.

Rahman Z, Singh P. 2018. Assessment of heavy metal contamination and $\mathrm{Hg}$-resistant bacteria in surface water from different regions of Delhi, India. Saudi J Biol Sci 25 (8): 1687-1695. DOI: 10.1016/j.sjbs.2016.09.018.

Rajbanshi A. 2008. Study on heavy metal resistant bacteria in Guheswori sewage treatment plant. Our Nat 6 (1): 52-57. DOI: $10.3126 /$ on.v6i1.1655.

Rasheed RO, HamaKarim TA. 2017. Impact assessment of wastewater and planning for a treatment plant within Sulaimani City, Iraq. Arab J Geosci 10 (23): 1-27. DOI: 10.1007/s12517-017-3298-0.

Rashid KhA. 2010. Environmental Implications of Tanjaro Waste Disposal site in the city of Sulaimani. [Dissertation]. Univ of Sulaimani, Iraq.

Ravanbakhsh S, Ali D, bidhendi N, Nasser M. 2009. Removal of Total Petroleum Hydrocarbons (TPHs) from Oil-Polluted Soil in Iran. Iran J Chem Chem Eng 28 (4): 105-113. DOI: 10.30492/IJCCE.2009.6839.

Samanta A, Bera P, Khatun M, Sinha C, Pal P. 2012. An investigation on heavy metal tolerance and antibiotic resistance properties of bacterial strain Bacillus sp . isolated from municipal waste. J Microbiol Biotech Res 2 (1): 178189.

Saran L, Pissarra T, Silveira G, Constancio M, de Melo W, Alves C. 2018. Land use impact on potentially toxic metals concentration on surface water and resistant microorganisms in watersheds. Ecotoxicol Environ Saf 166: 366-374. DOI: 10.1016/j.ecoenv.2018.09.093.

Satokari RE, Akkermans A, Saarela M, De Vos M. 2001. Bifidobacterial diversity in human feces detected by genusspecific PCR and denaturing gradient gel electrophoresis. Appl Environ Microbiol 67 (2): 504-513. DOI: 10.1128/AEM.67.2.504-513.2001. 
Shukla D, Jain N. 2017. Assessment of physico-chemical and bacteriological water quality parameters: a review. Intl J Pharm Life Sci 5 (2): 1-17.

Silva A, Ribeiro M, Souza S, Teixeira P, Silva Filho R, Meirelles C, Melo Bento C, Hofer E. 2012. Heavy metal tolerance (Cr, $\mathrm{Ag}$ and $\mathrm{Hg}$ ) in bacteria isolated from sewage. Braz $\mathrm{J}$ Microbiol 43 (4): 1620-1631. DOI: $10.1590 / \mathrm{S} 1517-$ 83822012000400047.

Srinath T, Verma T, Ramteke P, Garg K. 2002. Chromium (VI) biosorption and bioaccumulation by chromate resistant bacteria. Chemosphere 48 (4): 427-435. DOI: 10.1016/S00456535(02)00089-9.
Sultan I, Ali A, Gogry F, Rather I, Sabir J, Haq R. 2020. Bacterial isolates harboring antibiotics and heavy-metal resistance genes co-existing with mobile genetic elements in natural aquatic water bodies. Saudi J Biol Sci 27 (10): 2660-2668. DOI: $10.1016 /$ j.sjbs.2020.06.002.

WHO [World Health Organization] 2011. Water quality for drinking: WHO guidelines. $4^{\text {th }}$ ed. WHO, Geneva. DOI: 10.1007/978-1-4020-4410-6_184.

Yamina B, Tahar B, Laure M. 2012. Isolation and screening of heavy metal resistant bacteria from wastewater: A study of heavy metal co-resistance and antibiotics resistance. Water Sci Technol 66 (10): 2041-2048. DOI: 10.2166/wst.2012.355. 